\title{
The botanical provenance and taphonomy of Late Cretaceous Chatham amber, Chatham Islands, New Zealand
}

\author{
Chris Mays ${ }^{\mathrm{a}, \mathrm{b}, *}$, Andrew J. Coward ${ }^{\mathrm{b}}$, Luke A. O'Dell ${ }^{\mathrm{c}}$, Ralf Tappert ${ }^{\mathrm{d}}$ \\ a Department of Palaeobiology, Naturhistoriska riksmuseet, Box 50007, S-104 05 Stockholm, Sweden \\ b School of Earth, Atmosphere and Environment, Monash University, 9 Rainforest Walk, Clayton, Victoria 3800, Australia \\ c Institute for Frontier Materials, Deakin University, Locked Bag 20000, Geelong, Victoria 3220, Australia \\ d Department of Geology, Lakehead University, Thunder Bay, Ontario P7B 5E1, Canada
}

\section{A R T I C L E I N F O}

\section{Article history:}

Received 23 April 2018

Received in revised form 25 July 2018

Accepted 22 August 2018

Available online 18 September 2018

\section{Keywords:}

Amber

Chemotaxonomy

FTIR

${ }^{13} \mathrm{C}$ NMR

Cupressaceae

Principal component analysis

\begin{abstract}
A B S T R A C T
Fossil resin (amber) has been recently reported as common, but small, sedimentary components throughout the lower Upper Cretaceous (Cenomanian; 99-94 Ma) strata of the Tupuangi Formation, Chatham Islands, eastern Zealandia. From these deposits, resin has also been identified and obtained from well-preserved, coalified specimens of the conifer fossil Protodammara reimatamoriori Mays and Cantrill, 2018. Here, we employed attenuated total reflectance Fourier-transform infrared spectroscopy (ATR-FTIR) to both dispersed and in situ amber specimens. These resulted in very similar chemical signatures, indicating that these fossils are likely from the same or closely-related botanical sources. The FTIR data are typical of a conifer source within the 'cupressaceous resins' category of Tappert et al. (2011). Carbon-13 nuclear magnetic resonance spectroscopy ( ${ }^{13} \mathrm{C}$ NMR) facilitated the probable identification of these ambers as 'Class Ib' (sensu Anderson et al. 1992). Based on these spectral data sets, the likely botanical sources of the amber were either Araucariaceae or Cupressaceae; both of these conifer families were common and widespread in the Southern Hemisphere during the Cretaceous. However, the morphology and anatomy of $P$. reimatamoriori support an affinity to the latter family, thus indicating that the Cretaceous amber of the Chatham Islands was generally produced by members of the Cupressaceae. Comparing the FTIR data to the published spectra of modern resins, we also identify a band ratio which may aid in distinguishing between the FTIR spectra of Araucariaceae and Cupressaceae, and outline the limitations to this approach. A high concentration of ester bonds in Chatham amber specimens, which exceeds typical Cupressaceae resins, is probably caused by taphonomic alteration via thermal maturation. The source of thermal alteration was likely preburial wildfires, conditions for which $P$. reimatamoriori was adapted to as part of its life cycle. A comparison of ambers of the Chatham Islands with modern resins and amber from various localities in Australasia reveals that, taphonomic influences aside, Chatham amber has a unique signature, suggesting that members of the basal Cupressaceae (e.g., Protodammara) were not major contributors to other documented Australasian amber deposits. The closest analogy to Chatham amber deposits appears to be the Upper Cretaceous Raritan Formation, USA, which is characterised by its rich amber, charcoal and Cupressaceae fossil assemblages. This study further supports the hypotheses that the early Late Cretaceous south polar forests were dominated by Cupressaceae, and regularly disturbed by wildfires.
\end{abstract}

Crown Copyright @ 2018 Published by Elsevier B.V. All rights reserved.

\section{Introduction}

At the start of the Late Cretaceous (Cenomanian-Turonian; 100-89 Ma), the world was experiencing intense and prolonged greenhouse conditions. Elevated atmospheric $\mathrm{CO}_{2}$ (Bice et al., 2006; Barclay et al., 2010; Mays et al., 2015a) led to some of the warmest temperatures in recorded Earth history (Friedrich et al., 2012). These climatic conditions promoted the proliferation of dense vegetation within the

\footnotetext{
* Corresponding author at: Department of Palaeobiology, Naturhistoriska riksmuseet, Box 50007, S-104 05 Stockholm, Sweden.

E-mail address: chris.mays@nrm.se (C. Mays).
}

polar circles of both the Northern (e.g., Herman and Spicer, 2010) and Southern (e.g., Mays et al., 2015b) hemispheres. Cretaceous warming was attended by the diversification and biogeographic spread of angiosperms towards the south polar regions (Drinnan and Crane, 1990; Cantrill and Poole, 2002). A unique example of the Cretaceous floras of the south polar regions are preserved in sedimentary sequences of the Chatham Islands, Zealandia. These sequences also contain abundant fossil resins (amber), which occur dispersed within the sediments and in situ with coalified and charcoalified plant fossils remains (Mays et al., 2017b). These fossils, Protodammara reimatamoriori Mays and Cantrill, 2018, are cone scales ('ovuliferous complexes' herein, sensu Escapa et al., 2016) commonly found amongst the Cenomanian (99-94 Ma) 
strata of the Chatham Islands, and exhibit a range of morphological and anatomical features indicative of the conifer family Cupressaceae. Furthermore, P. reimatamoriori specimens typically have copious in situ fossil resin ('amber' up to ca $42 \%$ of the total fossil volume; Mays and Cantrill, 2018), and their tendency to co-occur with dispersed fossil resin pieces suggests that these plants were primary contributors of the Chatham Islands Cretaceous amber deposits. Analogous to several modern fire-adapted taxa of pine (Pinaceae; e.g., Pinus banksiana Lamb.) and cypress (Cupressaceae; e.g., Widdringtonia Endl.), the adhesive property of resin in P. reimatamoriori would have played a key role in long-term seed retention (serotiny) by holding the mature seed cone closed (Mays et al., 2017b). As is common in extant serotinous plants, these adhesive bonds would break-down during a fire, facilitating seed dispersal in the post-fire environment (Lamont et al., 1991). The co-occurrence of high fossil resin and charcoal abundances has been noted amongst the mid-Cretaceous amber deposits of eastern USA; these resins have been inferred to be traumatically induced by wildfires (Jeffrey and Chrysler, 1906; Grimaldi et al., 2000). Protodammara reimatamoriori provides clues of a reproductive function of the Chatham Islands fossil resins, and as discussed herein, at least some of the midCretaceous ambers of eastern USA.

\subsection{Mid-Cretaceous geology and palaeontology of the Chatham Islands}

The Chatham Islands (Moriori: Rēkohu) are an archipelago in the south Pacific Ocean ( $\left.44^{\circ} \mathrm{S} 02^{\prime} \mathrm{S}, 176^{\circ} 26^{\prime} \mathrm{W}\right)$, and situated near the eastern margin of Zealandia, a mostly submerged subcontinent which also includes New Zealand, Lord Howe Island, New Caledonia and Campbell Island (Fig. 1). During the early Late Cretaceous, this region was still integrated into the supercontinent Gondwana, and situated within the south polar circle $\left(75-80^{\circ} \mathrm{S}\right.$; Markwick et al., 2000). Eastern Zealandia was undergoing an interval of extensional tectonics prior to seafloor spreading between Zealandia and Australo-Antarctica (Sutherland, 1999; Schellart et al., 2006). The Chatham Islands region was largely emergent, with paralic, fluviodeltaic depositional conditions (Campbell et al., 1993). These palaeoenvironments are reflected in the ca $400 \mathrm{~m}$ thick outcrop successions of the Tupuangi Formation (Campbell et al., 1993; Mays and Stilwell, 2013). Amongst published records, this unit has only been definitively recorded in outcrops of Pitt Island (Moriori: Rangihaute) of the Chatham Islands (Wood et al., 1989).

The plant fossils of the Tupuangi Formation include abundant gymnosperm leaves, seeds, seed cones and pollen (Pole and Philippe, 2010; Mays, 2015; Mays et al., 2015a, 2017c), diverse angiosperm pollen (Mays, 2015) and leaves (C.M., pers. obs.), and a low diversity understorey of ferns, lycophytes and bryophytes (Mays et al., 2015b). Whilst pollen representatives of the three 'southern conifer' families (Araucariaceae, Podocarpaceae and Cupressaceae) are very common, these strata have a remarkably high abundance of Cupressaceae pollen (Mays, 2015), as well as fertile organs (Mays et al., 2017b,c), when compared to other Cretaceous Gondwanan localities. This suggests that the early Late Cretaceous flora of the south polar region was dominated by members of this family. Macrofloral fossils typically have a coalified preservation style, and three-dimensional fossils show some distortion due to compaction (Mays et al., 2017a). Of the 21 macerated sediment samples examined from the Cenomanian section of the Tupuangi Formation, fossil resin specimens were recovered from all but one (Mays et al., 2017b); these are dispersed, small (typically $<1 \mathrm{~cm}$ in length), and generally tubular (Fig. 2C). These tubular resin specimens are of similar sizes and shapes of the resin canals of the common cupressaceous conifer fossil P. reimatamoriori (Mays and Cantrill, 2018; Fig. 2A, C-F). Whilst widely dispersed throughout the studied succession, the fossil resins typically occur in small quantities; however, in some samples, the total mass of the resin can be almost as great as other maceral components such as charcoalified or coalified wood remains (Mays et al., 2017b, table DR1 therein). Based on the palynostratigraphy (Mildenhall, 1994; Mays and Stilwell, 2013), all strata identified with resin correlate to the Ngaterian-Arowhanan New Zealand chronostratigraphic stages (mid- to upper Cenomanian; ca 99-94 Ma, Raine et al., 2015).

\subsection{Chemotaxonomy of resins and amber}

Amber is developed through the gradual polymerisation and fossilisation of certain plant resins over geological time. This process results in a macromolecular, highly cross-linked polymer encompassing a

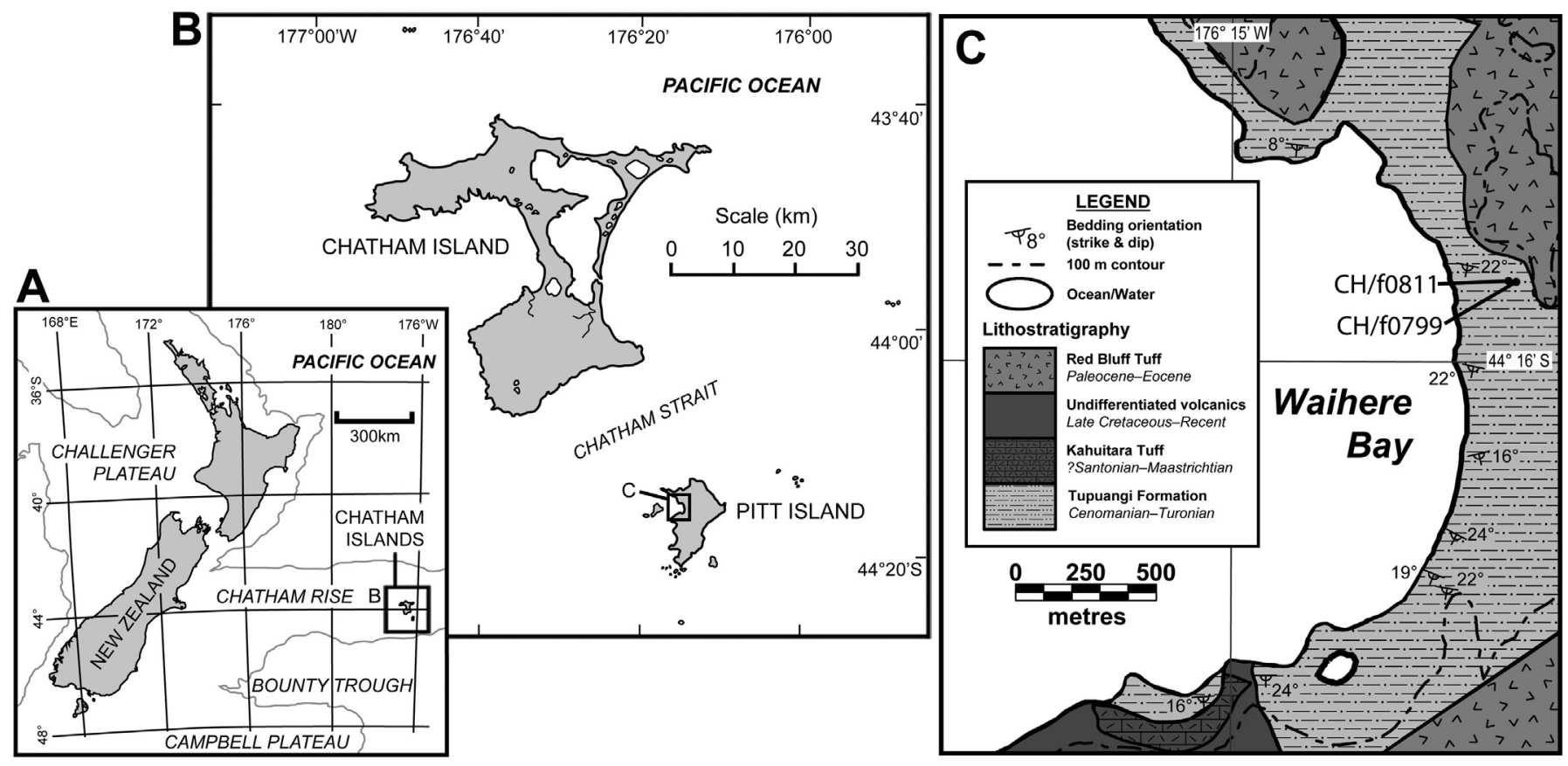

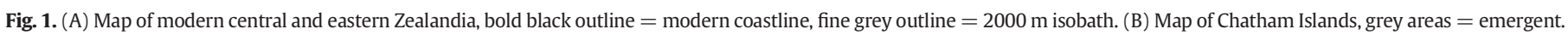
(C) Geological map of Waihere Bay outcrop successions, northwest Pitt Island. Modified from Mays et al. (2015b) with permission. 

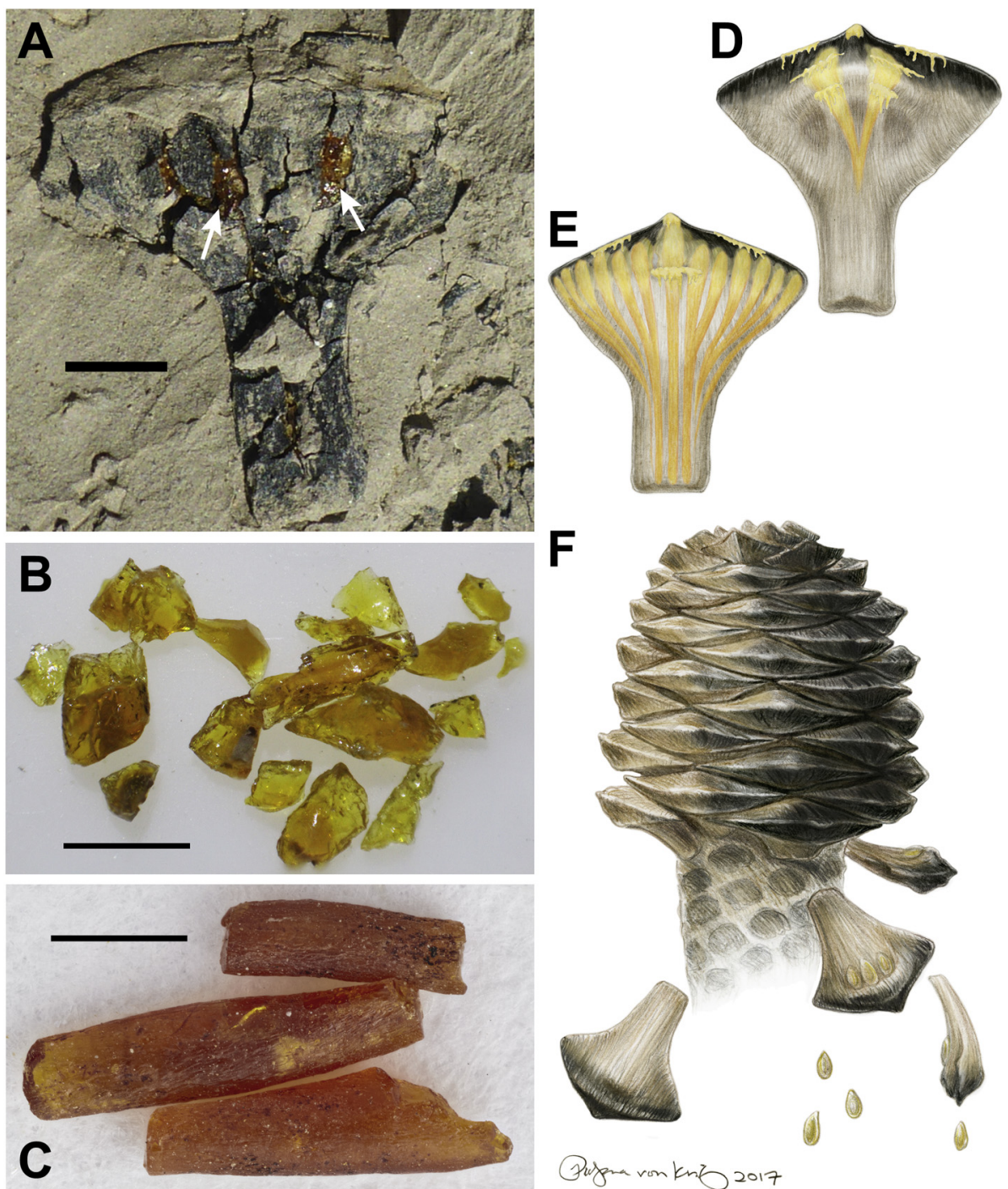

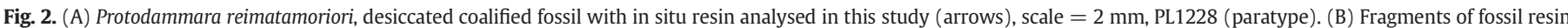

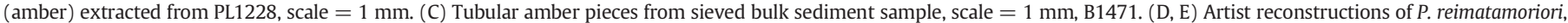

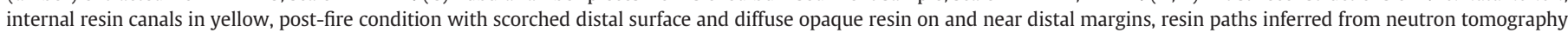

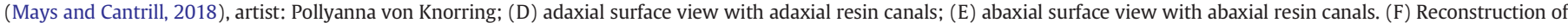
numerous specimens of $P$. reimatamoriori attached to cone or in the process of post-fire shedding, artist: Pollyanna von Knorring.

heterogenous mix of occluded, non-polymerised compounds (Langenheim, 2003). The exact chemical composition of both the macromolecular phase and occluded compounds may vary significantly between samples, dependent largely on the specific plant taxon from which the original resin was derived. This variability provides a reasonable method for determining botanical provenance, as long as the chemical structure can be sufficiently characterised (e.g., Langenheim and Beck, 1965). Initial studies investigating amber structural chemistry using pyrolysis-gas chromatography-mass spectrometry (Py-GC-MS; Anderson and Winans, 1991; Anderson et al., 1992) categorised five classes of amber based on molecular differences within the macromolecular structure ('classes I-V'). In parallel to this approach, analysis by solid-state carbon nuclear magnetic resonance $\left({ }^{13} \mathrm{C}\right.$ NMR; Lambert et al., 1985, 1988, 1990, 1993, 2008; Lambert and Poinar, 2002) identified four world-wide groupings of amber ('groups A-D') by phenomenological distinctions between ${ }^{13} \mathrm{C}$ NMR spectra. These assignments were later found to correspond to subdivisions of Class I and II amber, as identified by Py-GC-MS (Lambert et al., 2008). Of the two classes, Class I ambers, composed of polymers of labdanoid diterpenes, are the most widespread, having been associated with resiniferous gymnosperms and select angiosperm families. Class I ambers can be further divided into four subclasses based on stereochemical and compositional differences (Anderson et al., 1992; Poulin and Helwig, 2012). Class Ia ambers (corresponding to Group C), also known as 'Baltic amber' due to their abundance across northern Europe, are defined by the presence of succinic acid within the macromolecular structure. The botanical provenance of these ambers ultimately remains unknown, although various members of Araucariaceae and Pinaceae have long been proposed (see review by Langenheim, 2003). However, a combination of FTIR and time of flight-secondary ion mass spectrometry have recently revealed Pinaceae and Sciadopityaceae as the most likely candidate groups (e.g., Wolfe et al., 2009, Wolfe et al., 2016). Class Ib ambers (Group A) lack succinic acid but remain otherwise chemically equivalent to Class Ia (Lambert et al., 2008). Class Ib or Group A ambers are widespread, having been identified in both Northern and Southern hemispheres, including Australia, Zealandia, North America, Greenland, Europe and Asia (e.g., Lambert et al., 1988, 1990, 1993; Coward et al., 2018), and recent preliminary evidence in subSaharan Africa (Perrichot et al., 2016). Class Ib ambers have been linked to both araucarian and cupressaceous sources (e.g., Lambert et al., 1993; 
Anderson, 2006), most notably the araucarian genus Agathis (Lyons et al., 2009). Class Ic ambers (corresponding to Group D) are stereoisomers of Class Ib, and likewise do not possess succinic acid. They have been identified in South America, Africa and the Caribbean where they have been strongly associated with the Fabaceae genus Hymenaea (Anderson, 1995). A recently established subclass of amber, Class Id, is structurally comparable to Class la, but with ozol moieties cross-linked with succinic acid, rather than communol found in Class Ia (Poulin and Helwig, 2012, 2014). More recently, analyses employing Fourier transform infrared spectroscopy (FTIR; Tappert et al., 2011), carbon $\left({ }^{13} \mathrm{C}\right)$ NMR (Lambert et al., 2010, 2012) and proton $\left({ }^{1} \mathrm{H}\right)$ NMR (Lambert et al., 2007, 2012) have enabled further subdivisions of amber and resin classes, providing the ability to successfully distinguish between modern araucarian, cupressaceous and pinaceous resins. However, the application of these procedures to in situ ambers remains largely untested. These amber classes and their correlative NMR groups and probable botanical sources are summarised in Table 1 .

Several previous studies have examined the chemical signatures of resin found within the resin canals of modern and fossilised fertile plant organs, e.g., seed cones and/or ovuliferous complexes (Anderson and Lepage, 1995; Grimaldi et al., 2000; Otto et al., 2002a,b, 2003, 2007). These studies have demonstrated the utility of targeting fertile fossils for constraining amber chemotaxonomic interpretations because they are dense in distinctive characters, facilitating accurate identification and phylogenetic placement. By establishing these affinities, the same chemical analyses can be applied to dispersed fossil resins and identify their botanical sources with confidence. Here, we apply this rationale by using ${ }^{13} \mathrm{C}$ NMR and ATR-FTIR on in situ resins from $P$. reimatamoriori, a species of ovuliferous complex common amongst the Cenomanian strata of the Chatham Islands. By characterising the chemical signatures of these specimens, we aim to: (1) test whether the dispersed resins and $P$. reimatamoriori had comparable botanical sources; and (2) further delineate the chemotaxonomic variability of Cupressaceae by fingerprinting an extinct stem group of this family.

\section{Materials and methods}

All samples were collected from outcrops of the Tupuangi Formation, Pitt Island, Chatham Islands, New Zealand. Fossil material was collected by C.M., D.J. Cantrill, P. Viegas, and T. Ziegler during JanuaryFebruary, 2016. Fossil resin has been reported from 20 horizons of this unit (Mays et al., 2017b) from both Waihere Bay and Tupuangi Beach (northwestern and northeastern Pitt Island, respectively). The fossil resins were found amongst poorly to moderately consolidated, wellsorted, grey-light brown, siltstone to medium sandstone facies. The samples analysed in this study were from the Ngaterian (midCenomanian) localities $\mathrm{CH} / \mathrm{f0799}$ (co-ordinates: $44^{\circ} 15^{\prime} 53.2^{\prime \prime} \mathrm{S} ; 176^{\circ}$ $14^{\prime} 17.1^{\prime \prime} \mathrm{W}$ ) and $\mathrm{CH} / \mathrm{f0} 811$ (co-ordinates: $44^{\circ} 15^{\prime} 53.2^{\prime \prime} \mathrm{S}$; $176^{\circ} 14^{\prime}$ $17.5^{\prime \prime} \mathrm{W}$; Fig. 1). These correspond to the stratigraphic heights of 147 and $142 \mathrm{~m}$ of the stratigraphic section exposed at Waihere Bay, respectively (Mays and Stilwell, 2013, Fig. 4 therein). Plant fossil samples (prefix 'PL') and bulk sediment samples (prefix 'B') have been assigned unique sample registration numbers. Individual specimens recovered from the same bulk sample were given letter specimen codes. Fossil and sediment samples are curated at GNS Science, Lower Hutt, New Zealand.

Compression fossil photographs were taken using a Canon EOS

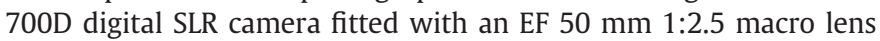
(Fig. 2A); resin fossil photographs were taken using a Leica M205 C stereo microscope equipped with a Leica DFC290 HD digital camera (Fig. 2B, C). All photographs are composite images, consisting of multiple photographs taken at different focal depths, which were then digitally processed to increase the depth of field; this was performed with the 'Auto-Blend Layers' function in Adobe Photoshop CS6. Dispersed resin specimens were collected by soaking $1252 \mathrm{~g}$ of sedimentary rock from the target horizon at $\mathrm{CH} / \mathrm{f0} 799$ in $1 \% \mathrm{HCl}$ (diluted with deionised water) for ca 14 days, and gently sieving at $0.5 \mathrm{~mm}$ with running water. This sample was selected because it contained the highest abundance of dispersed resin; other samples failed to reach the minimum mass of clean, uncontaminated resin required for both valid ${ }^{13} \mathrm{C}$ NMR and ATR-FTIR spectra. Macerated sediments were sorted with a Leica M60 reflected light stereomicroscope, and dried in an oven at $60{ }^{\circ} \mathrm{C}$ for $24 \mathrm{~h}$ before weighing.

ATR-FTIR spectra were collected at Monash University's School of Chemistry by A.C. using an Agilent Technologies Cary 630 FTIR with a diamond ATR accessory. Prior to sample acquisition, the accessory was cleaned with acetone, after which an open-air background spectrum was obtained. For the analysis, approximately 5-10 mg of tubular in situ amber was extracted from the resin canals of the coalified and desiccated remains of one of the P. reimatamoriori Mays and Cantrill 2018 paratype specimens (PL1228A; Fig. 2A; the impression fossil of this specimen was illustrated by Mays et al., 2017b, Fig. 2B). The resin was cleared of all potential inclusions, contamination and surface alterations, then crushed and placed on the accessory. The absorbance spectrum was obtained across the range of $4000-650 \mathrm{~cm}^{-1}$, with 64 scans

Table 1

Probable botanical sources, principle monomers and corresponding solid-state ${ }^{13} \mathrm{C}$ NMR groups of amber classes

\begin{tabular}{|c|c|c|c|c|}
\hline \multicolumn{5}{|c|}{ Amber classes and their correlative ${ }^{13} \mathrm{C}$ NMR groups and botanical sources } \\
\hline $\begin{array}{l}\text { Amber } \\
\text { class }^{1}\end{array}$ & Subclass $^{1}$ & $\begin{array}{l}\text { Solid-state }{ }^{13} \mathrm{C} \\
\text { NMR group }\end{array}$ & Predominant monomers & Closest botanical affinity \\
\hline \multirow[t]{7}{*}{ Class I } & Ia & Group C & $\begin{array}{l}\text { Regular labdanoids, including communic acid, communal and/or } \\
\text { biformene, with crosslinked succinic acid. }\end{array}$ & Pinopsida: Pinaceae (Pseudolarix ${ }^{2}$ ) \\
\hline & Ib & Group A & $\begin{array}{l}\text { Regular labdanoids including communic acid, communal and/or biformene } \\
\text { with self-crosslinking between moieties. }\end{array}$ & $\begin{array}{l}\left.\text { Pinopsida: Pinaceae (Pseudolarix }{ }^{2}\right) \text {, Cupressaceae } \\
\left(\text { Metasequoia }^{2}\right) \text {, Araucariaceae }\left(\text { Agathis }^{2}\right)\end{array}$ \\
\hline & Ic & Group D & Enantio labdanoids, including ozic acid, ozol and enantio biformenes. & Pinopsida: Pinaceae (Pseudolarix ${ }^{2}$ ) \\
\hline & & & & Magnoliopsida: Fabaceae (Hymenaea ${ }^{3}$ ) \\
\hline & & & & Pinopsida: Pinaceae (Pseudolarix ${ }^{2}$ ) \\
\hline & & & & Magnoliopsida: Fabaceae (Hymenaea ${ }^{3}$ ) \\
\hline & Id $^{4}$ & Unknown & $\begin{array}{l}\text { Enantio labdanoids, including ozic acid, ozol and enantio biformenes, } \\
\text { cross-linked with succinic acid }{ }^{5}\end{array}$ & Unknown \\
\hline Class II & & Group B & Polymers of sesquiterpenoids based on the cadinane skeleton & Magnoliopsida: Dipterocarpaceae $\left(\right.$ Shorea $\left.^{1}\right)$, Cornaceae $^{6}$ \\
\hline Class III & & Group $\mathbf{E}^{7}$ & Natural polystyrene & Magnoliopsida: Altingiaceae (Liquidambar ${ }^{1}$ ) \\
\hline Class IV & & Unknown & Non-polymeric sesquiterpenoids based on the cedrane carbon skeleton & Unknown \\
\hline Class $\mathbf{V}^{8}$ & & Unknown & $\begin{array}{l}\text { Non-polymeric abietane and pimarane diterpenoid carboxylic acid } \\
\text { structures }\end{array}$ & Pinopsida ${ }^{9}$ : Pinaceae $\left(\right.$ Pinus $\left.^{2}\right)$ \\
\hline
\end{tabular}

Note: the list of botanical sources includes the plant groups that have demonstrated an association with each class, but is not comprehensive.

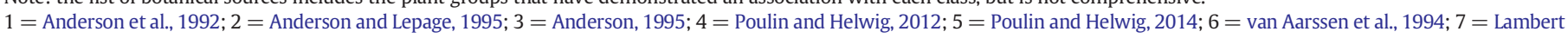
et al., 2015; 8 = Anderson and Botto, 1993; 9 = Beck, 1999. 
per sample at a resolution of $2 \mathrm{~cm}^{-1}$. Raw ATR-FTIR data are provided herein as Appendix 1.

Approximately, $25 \mathrm{mg}$ of tubular resin fragments from B1471 were available for solid-state ${ }^{13} \mathrm{C}$ CP-MAS NMR (carbon-13 crosspolarisation-magic angle spinning nuclear magnetic resonance) analysis. The NMR methods employed herein follow Coward et al. (2018), with the following exceptions: (a) 50,000 scans were acquired; (b) teflon spacers were included in the rotor to centre the smaller amount of sample relative to the RF coil; and (c) extra line broadening $\left(25 \mathrm{~Hz}\right.$ ) was applied to smooth the peaks. ${ }^{13} \mathrm{C}$ solid-state NMR data were collected from dispersed fossil resins of sample B1471, and the raw data are provided herein as Appendix 2. Amber from B1471 was selected as a target for comparison to PL1228A, as this hand sample exhibited multiple surface impressions of $P$. reimatamoriori. It also had sufficiently large volumes for ${ }^{13} \mathrm{C}$ solid-state NMR, and had a consistent, tubular shape, reminiscent of the shape of the resin canals observed in PL1228A. To ensure that B1471 was representative of $P$. reimatamoriori (PL1228A), six randomly selected fragments of tubular resin were analysed by ATR-FTIR; these six fragments were designated B1471A-F.

Principal component analysis (PCA) was conducted on: (1) ${ }^{13} \mathrm{C} N \mathrm{NM}$ data from B1471; and (2) the ${ }^{13} \mathrm{C}$ NMR data set of modern conifer resins compiled by Lambert et al. (2010, and references therein). Following Lambert et al. (2010), the following 19 chemical shifts or ranges were targeted for PCA because of their demonstrable utility in distinguishing different resin groupings: $\delta 13,18-20,25,28,30-31,34,38-40,43-44$, 46, 48-50, 52, 56-58, 72-74, 104-105, 106-108, 145, 154, 179, and 204. Ranges were employed for peaks, which are clearly related structurally, but do not always resonate at precise locations on the spectra. For standardisation, intensities were re-scaled on a 1 to 10 scale. The compiled, decimalized ${ }^{13} \mathrm{C}$ NMR data set was entered into PAST, a palaeontology statistics software package (Hammer et al., 2001). The results of the conifer ${ }^{13} \mathrm{C}$ NMR PCA are presented graphically in Appendix 3, and the data and principle component variables are in Appendix 4.

\section{Results}

\subsection{ATR-FTIR}

FTIR spectra for both amber samples, PL1228A and B1471, are presented in Fig. 3. The adsorption features of both spectra were extremely similar, differing only in the relative intensity of some peaks. The spectral similarities between the resin from the $P$. reimatamoriori paratype specimen (PL1228A) and the isolated specimens from B1471 imply a common fossil botanical source. Both spectra exhibited key absorption features characteristic of amber, as defined in previous studies (Guiliano et al., 2007; Tappert et al., 2011). Hydroxyl (OH) stretching of alcohols and acids is evident at $3400 \mathrm{~cm}^{-1}$ as a broad, shallow peak. Alkyl stretching peaks are located adjacent at 2924 and $2867 \mathrm{~cm}^{-1}$, corresponding to $\mathrm{CH}_{2}$ stretching and $\mathrm{CH}_{3}$ stretching, respectively. Another $\mathrm{CH}_{2}$ stretching feature at $2848 \mathrm{~cm}^{-1}$, usually present in cupressaceous resins as a small peak (Tappert et al., 2011), is instead evident as a shoulder in both spectra. Two additional alkyl peaks are located at 1448 and $1378 \mathrm{~cm}^{-1}$, and are attributed to $\mathrm{CH}_{2}$ and $\mathrm{CH}_{3}$ bending and $\mathrm{CH}_{3}$ bending, respectively. The most prominent absorption peak in both spectra, at $1692 \mathrm{~cm}^{-1}$, corresponds to carbonyl $(C=0)$ stretching in carboxylic acid groups, while the region from 1300 to $1100 \mathrm{~cm}^{-1} \mathrm{can}$ be assigned to the stretching of $\mathrm{C}-\mathrm{O}$ single bonds of acids, alcohols and esters. All spectral features below $1100 \mathrm{~cm}^{-1}$ cannot be easily interpreted, with the exception of a prominent peak at $887 \mathrm{~cm}^{-1}$ caused by the $\mathrm{CH}$ bending of exomethylene groups $\left(\mathrm{C}=\mathrm{CH}_{2}\right)$. Two other peaks attributed to exomethylene stretching, present at 1640 and $3048 \mathrm{~cm}^{-1}$ in other ambers (e.g., Dominican amber, Class Ic, Grimalt et al., 1988; Baltic amber from Poland, Class Ia, Guiliano et al., 2007; New Zealand amber, Class Ib, Seyfullah et al., 2015), were not observed.

\section{2. ${ }^{13} \mathrm{C}$ solid-state NMR}

The solid state ${ }^{13} \mathrm{C}$ solid-state NMR spectrum for B1471 is displayed in Fig. 4, with the assignment of resonance signals following that of Lambert and Frye (1982). Resonances corresponding to saturated carbons extend from 10 to $80 \mathrm{ppm}$. Six of these peaks, at 12, 19, 27, 32, 36 and $42 \mathrm{ppm}$, can be assigned variously to methyl $\left(\mathrm{CH}_{3}\right)$, methylene $\left(\mathrm{CH}_{2}\right)$ and methine $(\mathbf{C H})$ carbons. Two further peaks correspond to carbon atoms singly bonded to oxygen, with carbons adjacent to ester groups $\left(\mathrm{CO}_{2} \mathrm{CH}_{2}\right)$ resonating at $55 \mathrm{ppm}$ and carbons adjacent to either alcohols $\left(\mathrm{CH}_{2} \mathrm{OH}\right)$ or ethers $\left(\mathrm{CH}_{2} \mathrm{OC}\right)$ resonating at $72 \mathrm{ppm}$. The unsaturated region is represented by four peaks between 100 and 150 ppm, with two resonances for carbons of internal, disubstituted $(-\mathrm{CH}=\mathrm{CH}-)$ and trisubstituted $(>\mathbf{C}=\mathrm{CH}-)$ alkenes at 124 and $133 \mathrm{ppm}$, and two weaker resonances for exomethylene carbons at $105\left(\mathbf{C H}_{2}=\mathrm{C}\right)$ and $146 \mathrm{ppm}\left(\mathrm{CH}_{2}=\mathbf{C}\right)$. Carbonyl carbons of acids and esters are found in the region from 170 to 190 ppm, characterised by a

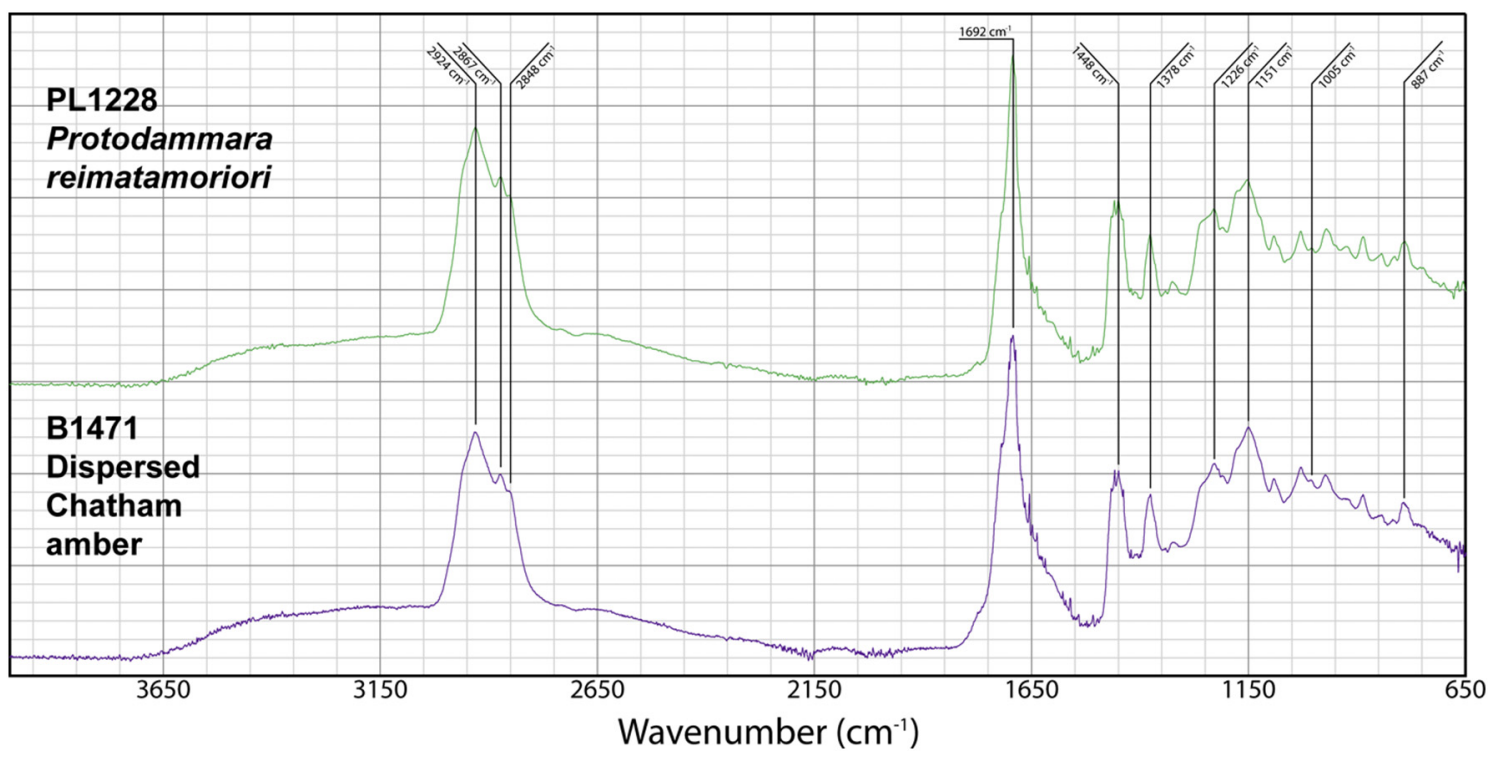

Fig. 3. ATR-FTIR spectra of Chatham Island amber samples examined in this study. All major and unique peaks have been marked with their corresponding wavenumber. 


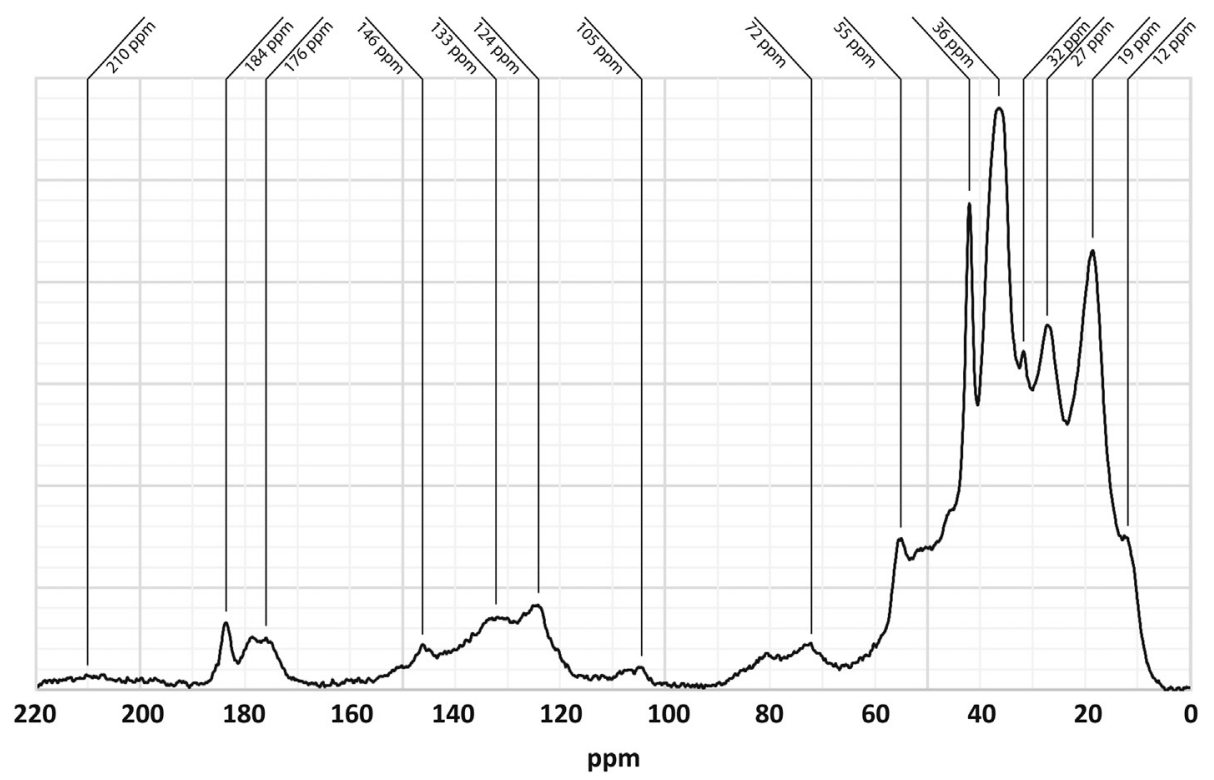

Fig. 4. ${ }^{13} \mathrm{C}$ solid-state CPMAS NMR spectrum of representative amber specimen from B1471. All major resonances have been marked with their corresponding chemical shift.

prominent peak at $184 \mathrm{ppm}$, representing carboxylic acids $\left(\mathrm{CO}_{2} \mathrm{H}\right)$, and a second peak at $176 \mathrm{ppm}$ attributed to esters $\left(\mathrm{CO}_{2} \mathrm{R}\right)$. An additional shallow, broad resonance is present at $210 \mathrm{ppm}$, likely corresponding to aldehyde $(\mathrm{R}(\mathbf{C}=0) \mathrm{H})$ or ketone $\left(\mathrm{R}(\mathbf{C}=0) \mathrm{R}^{\prime}\right)$ carbons.

Principal component analysis of the compiled ${ }^{13} \mathrm{C}$ NMR data revealed distinct clusters for the three analysed extant conifer families: Araucariaceae, Cupressaceae and Pinaceae (as established previously by Lambert et al., 2010). However, the $P$. reimatamoriori-equivalent sample (B1471) did not plot within any of the extant conifer family clusters. The first two principal components, PC1 and PC2, comprised $65.6 \%$ of the total variance in the data set, and are presented graphically in Appendix 3.

\section{Discussion}

\subsection{Chatham amber classification: ${ }^{13} \mathrm{C}$ solid-state NMR}

The ${ }^{13} \mathrm{C}$ solid-state NMR spectra of the fossil resins analysed in this study (herein referred to as 'Chatham amber'), including those associated with the conifer fossils $P$. reimatamoriori, were comparable to several previously classified modern and fossil resins. Specifically, these resins correspond to the Class Ib resins first classified with Py-GC-MS by Anderson et al. (1992). ${ }^{13} \mathrm{C}$ solid-state NMR has revealed a consistent spectral signature from numerous modern and fossil Class Ib resins the world over; these correspond to Group A (see Lambert et al., 2008, 2015). This is indicated by comparable aliphatic, olefinic and carbonyl regions and the absence of any significant succinic acid resonances at $170 \mathrm{ppm}$ (which are characteristic of Class la resins). Class Ib (or Group A) fossil resins are consistently associated with conifers, particularly Araucariaceae (Anderson et al., 1992; Lambert et al., 1993, 2008, 2015), but a broader range of botanical sources have been proposed, most notably: Cupressaceae (Anderson et al., 1992; Anderson and Lepage, 1995; Anderson, 2006). To date, Group A amber has been associated only with resins of Araucariaceae (e.g., the copious resin-producer Agathis australis, New Zealand; Lambert et al., 1993). The close association of Group A with the polygenetic Class Ib (Lambert et al., 2008) suggests that ${ }^{13} \mathrm{C}$ solid-state NMR studies of modern and fossil cupressaceous resins of known affinity should verify a much broader range of botanical sources associated with Group A. The similarity in resin chemical signatures of Araucariaceae and Cupressaceae is reflected by their close phylogenetic relationship within the Order Pinales (Mao et al.,
2012). When applied to the chemotaxonomy of resins, the phylogenetic hypothesis implies these basal members of Cupressaceae should share a greater degree of similarity in chemical composition with Araucariaceae than the more derived Cupressoideae clade (sensu Farjon, 2005). Protodammara has been inferred as a member of the taxodioid Cupressaceae (sensu Rothwell et al., 2011), an early divergent stem group within Cupressaceae (Mays and Cantrill, 2018). The closely allied chemotaxonomic signatures of this taxon and Araucariaceae may be explained, at least in part, by the phylogenetic placement of Protodammara amongst the basal Cupressaceae.

The principal component analysis employed herein was inconclusive, as it failed to support a specific botanical affinity for Protodammara amongst the three analysed extant conifer families (Appendix 3). Coward et al. (2018) demonstrated similar ${ }^{13} \mathrm{C}$ NMR spectra between 'fresh' unaltered Class Ib ambers and those which have undergone heavy visible alteration (e.g., colour alteration, fragmentation, powdering, increase in opacity) as a result of geological processes. As such, taphonomic alteration via geological processes (e.g., age, temperature, pressure, groundwater interaction) can be tentatively excluded as a cause of statistical variance in this sample of Class Ib amber. At present, the small sample size precludes any solid conclusions about the botanical source based on statistical analyses of the ${ }^{13} \mathrm{C}$ NMR data.

\subsection{Chatham amber classification: ATR-FTIR}

Tappert et al. (2011) successfully employed micro-FTIR spectroscopy to subdivide 82 modern resins into two distinct populations: (1) 'pinaceous resins', produced exclusively by members of Pinaceae; and (2) 'cupressaceous resins', produced primarily by Araucariaceae and Cupressaceae, in addition to members of Sciadopityaceae and Podocarpaceae. These two populations were distinguished through the comparison of four diagnostic band ratios of key absorption features. The Chatham amber ATR-FTIR spectra are typical of "cupressaceous resin', reflected by the comparable spectral characters within three of the four signature band ratios identified by Tappert et al. (2011, p. 125), lacking only the characteristic alkyl peak at $2548 \mathrm{~cm}^{-1}$ (Fig. 5).

In this study, we identified a fifth band ratio, applicable to the distinction between Araucariaceae and Cupressaceae resins:

$r=\frac{1151 \mathrm{~cm}^{-1}}{1161 \mathrm{~cm}^{-1}}$ 

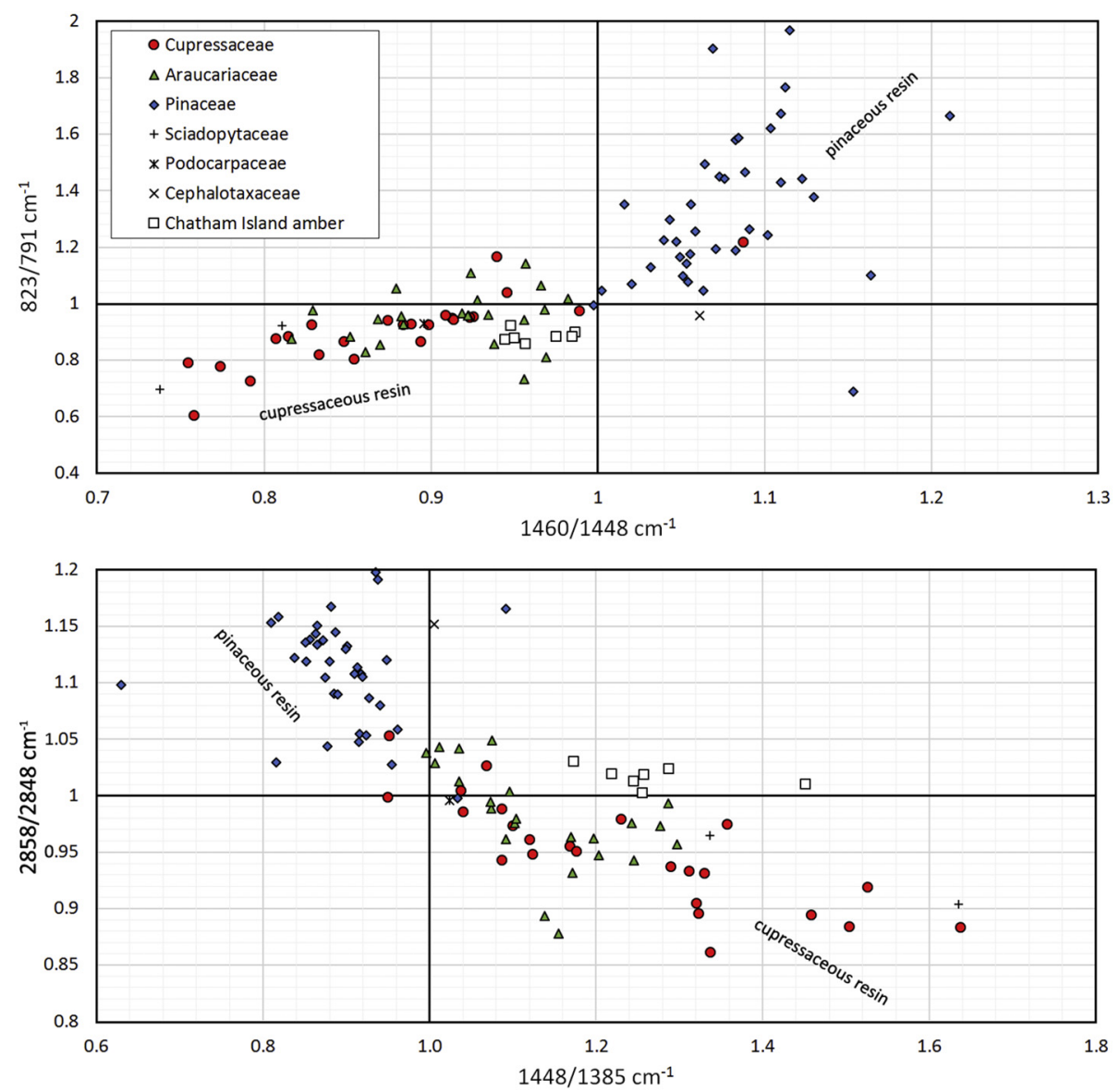

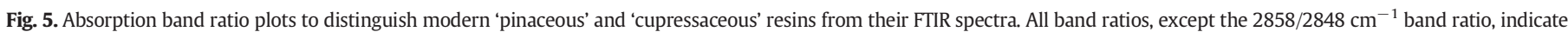

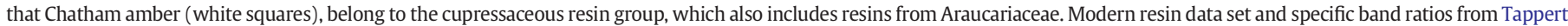
et al. (2011)

This band ratio provides a quantitative measurement of the relative intensity of an absorption feature at $1151 \mathrm{~cm}^{-1}$, attributed to the stretching of ester C-O bonds (Guiliano et al., 2007). This feature produces a prominent peak in the FTIR spectra of most Araucariaceae fossil and modern resins (e.g., Lyons et al., 2009; Tappert et al., 2011; Seyfullah et al., 2015). By contrast, in most Cupressaceae resins, the $1151 \mathrm{~cm}^{-1}$ absorption feature is expressed either as a minor peak or shoulder (Fig. 6).

The $1151 / 1161 \mathrm{~cm}^{-1}$ band ratio was tested using the modern resin micro-FTIR data base collected by Tappert et al. (2011), a further six micro-FTIR spectra of modern resins from Agathis lanceolata, Agathis ovata, Araucaria columnaris and Araucaria humboldtensis, and the seven ATR-FTIR spectra from PL1228A and B1471. The results are plotted in Fig. 7. Araucariaceae resins typically showed a higher absorbance of the $1151 \mathrm{~cm}^{-1}$ absorption feature when compared to Cupressaceae resins. However, three exceptions to this trend were observed: (1) Widdringtonia dracomontana (Cupressaceae) which displayed a peak at $1151 \mathrm{~cm}^{-1}$, similar to some Araucariaceae samples; (2) one of the three Araucaria cunninghamii resin samples, which did not possess any peak within the $1150-1160 \mathrm{~cm}^{-1}$ region; and (3) both samples of Agathis ovata, which likewise exhibited no peak between 1150 and $1160 \mathrm{~cm}^{-1}$. Due to the prominent absorption at $1151 \mathrm{~cm}^{-1}$, all seven $P$. reimatamoriori amber samples from the Chatham Islands, from both B1471 and PL1228A, plotted well within the expected field for Araucariaceae resins. This conflicts with morphological and anatomical data associating P. reimatamoriori with Cupressaceae (Mays and Cantrill, 2018). Possible reasons for this discrepancy are discussed below.
As the FTIR data employed to identify this band ratio (Fig. 7) were derived entirely from the spectra of modern resins, it is uncertain if this classification scheme to distinguish Cupressaceae and Araucariaceae resins may be safely extrapolated to fossil resins. Previous FTIR studies have shown modern resins to be chemically comparable to their fossilised equivalents (Tappert et al., 2011). However, ester bonds, to which the $1151 \mathrm{~cm}^{-1}$ absorption feature is attributed, remain susceptible to chemical alteration, specifically through the hydrolysis of esters into carboxylic acids (Pastorelli et al., 2013). Furthermore, the formation of ester bonds in Class Ib resins may occur during the maturation process due to the self-crosslinking of communol and communic acid units (Poulin and Helwig, 2015). The application of intense heat may further accelerate this process, potentially by the evaporation of water molecules from the amber structure. In a heat treatment experiment performed by Wang et al. (2017) on Baltic amber (Class Ia), thermal treating at $200{ }^{\circ} \mathrm{C}$ for $3-6 \mathrm{~h}$ was found to cause significantly increased absorption in FTIR spectra at multiple points, including peaks at 1732 and $1160 \mathrm{~cm}^{-1}$, attributed by Guiliano et al., 2007) to the stretching of carbonyl and $\mathrm{C}-\mathrm{O}$ bonds in esters. Comparable absorbance increases can be observed in other heat treatment studies (Martínez-Richa et al., 2000; Abduriyim et al., 2009), demonstrating that such changes are not limited to Class Ia ambers. The increased absorbance around $1160 \mathrm{~cm}^{-1}$ is of particular importance, as such a change would likely bias the results of the newly identified band ratio towards an araucarian result. Applying this argument to Chatham amber, it remains possible that wildfires, which have been inferred as a trigger mechanism for seed dispersal of $P$. reimatamoriori (Cupressaceae; Mays et al., 2017b), also facilitated ester formation within the resin, resulting in this part of the FTIR spectrum 


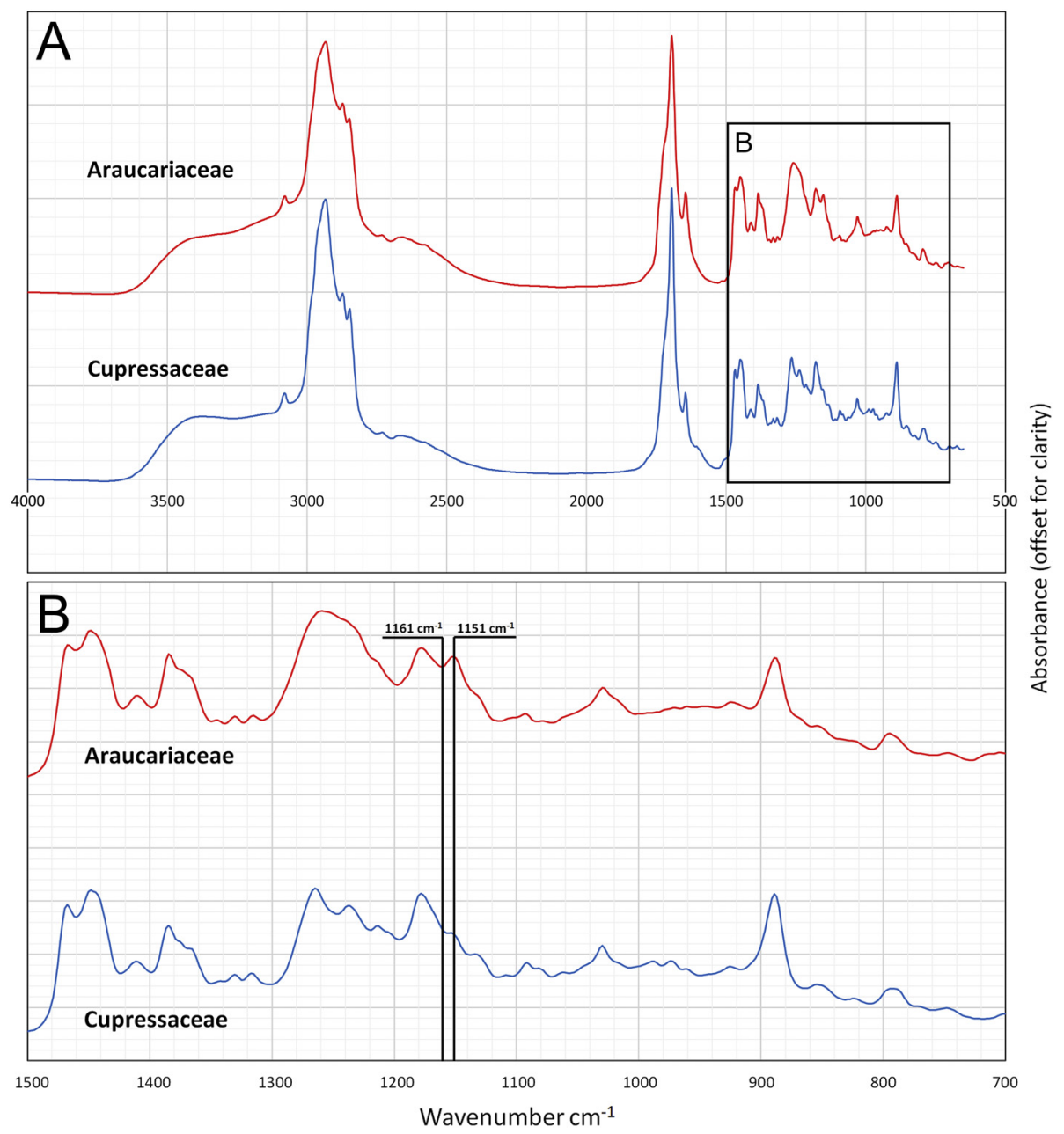

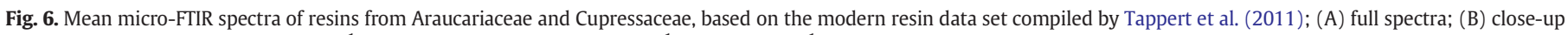

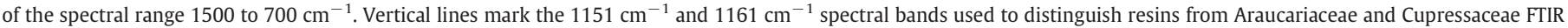
spectra herein (Fig. 7).

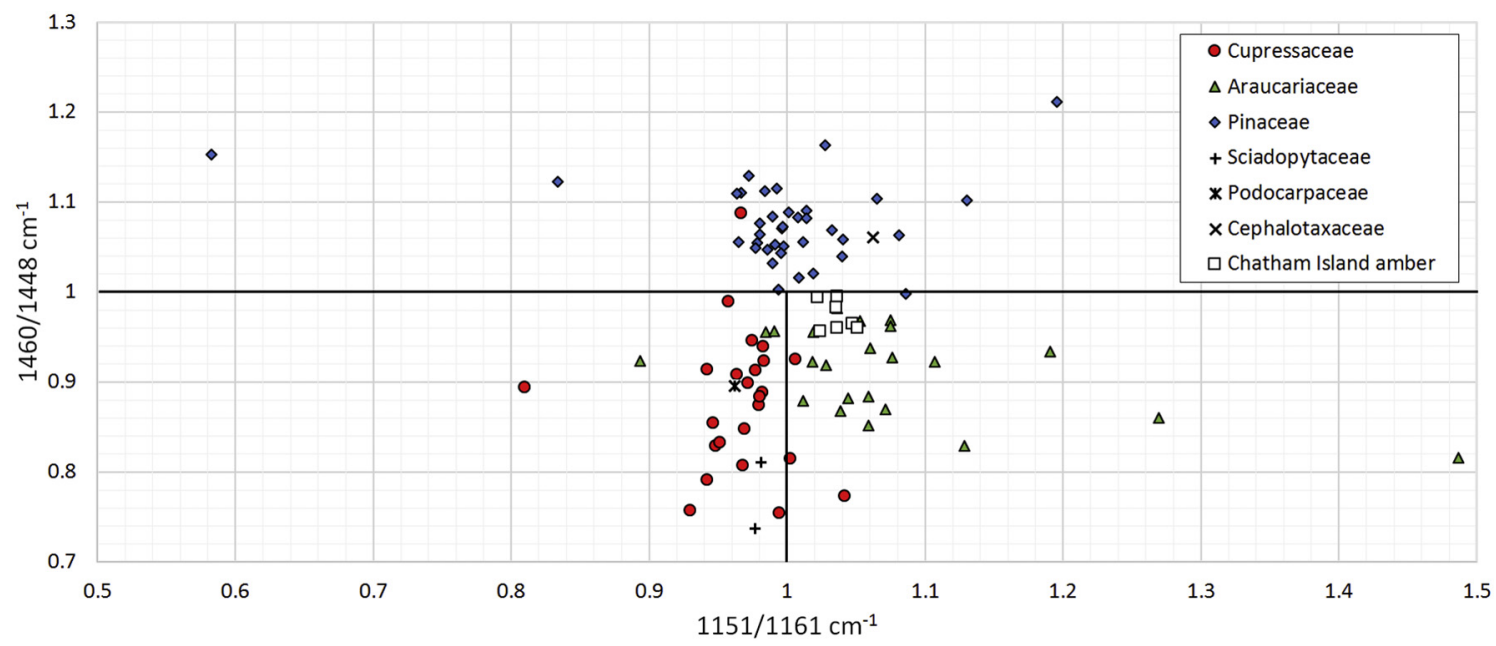

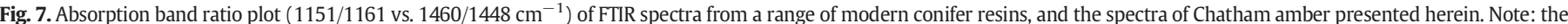

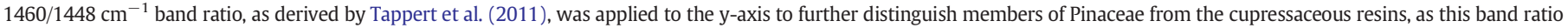

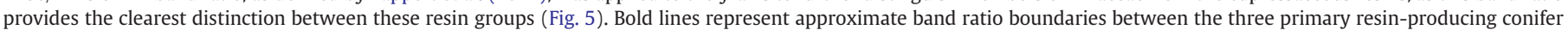
families, Araucariaceae, Cupressaceae and Pinaceae. Modern resin data set from Tappert et al. (2011). 
approximating that of araucariaceous resins. Although the $1151 \mathrm{~cm}^{-1}$ absorption feature is generally useful to distinguish between resins of Cupressaceae and Araucariaceae (particularly modern resins), this study demonstrates the importance of taphonomic control for the classification of amber types (e.g., comparable pre- and post-burial conditions).

\subsection{Comparison to other Australasian ambers}

The FTIR and ${ }^{13} \mathrm{C}$ solid-state NMR spectra of Chatham amber were found to be comparable, to varying degrees, with other Class Ib fossil resins common across the Australasian region. This includes araucarian-derived Eocene to Miocene ambers from New Zealand (Lambert et al., 1993; Lyons et al., 2009; Seyfullah et al., 2015), Eocene amber sourced from two Australian deposits at Strahan, Tasmania, and Anglesea, Victoria (Coward et al., 2018, 'Type A' amber therein), and Miocene amber originating from the Morwell and Yallourn coals seams of Latrobe Valley, Victoria, Australia (Lambert et al., 1993; Lyons et al., 2009). Each amber population, while possessing broad similarities between their FTIR and ${ }^{13} \mathrm{C}$ NMR spectra, can sometimes be differentiated through differences in the positions and intensities of certain peaks. Regardless of the mechanisms (whether botanic, biostratinomic or diagenetic), the differences in spectral signature between Australasian ambers, particularly in ${ }^{13} \mathrm{C}$ solid-state NMR, likely provide reliable chemical 'fingerprints' for assessing the provenance of isolated ambers. These are discussed in further detail below.

Some of the FTIR and ${ }^{13} \mathrm{C}$ solid-state NMR spectral dissimilarities between Chatham amber and those previously described from Australasia can be attributed to alteration and maturation processes rather than taxonomic differences. Specifically, the former is characterised by reduced or absent exomethylene peaks in both FTIR and ${ }^{13} \mathrm{C}$ solid-state NMR, the lack of which has been identified as a common reaction pathway upon the maturation or ageing of amber (Lambert et al., 1993; Martínez-Richa et al., 2000; Shashoua et al., 2005; Pastorelli et al., 2011). Other characteristic features of the Chatham amber FTIR and ${ }^{13} \mathrm{C}$ solid-state NMR spectra could not be attributed to alteration or maturation processes, and are likely caused by differences in botanical sources. Chatham amber lacked several key FTIR peaks common amongst other Class Ib Australasian amber and cupressaceous resins, including the peak at $2847 \mathrm{~cm}^{-1}$, normally characteristic of the cupressaceous group (Tappert et al., 2011), and peaks at 1178 and $1265 \mathrm{~cm}^{-1}$. Amongst Australasian amber and resins, the absences of both the 1178 and $1265 \mathrm{~cm}^{-1}$ peaks are spectral features shared only by some New Zealand amber (Lyons et al., 2009) and by modern resins of Agathis australis (Tappert et al., 2011; Seyfullah et al., 2015). The ${ }^{13} \mathrm{C}$ solid-state NMR spectrum of Chatham amber also exhibited a very high $42 \mathrm{ppm}$ alkyl peak, second in height only to the principal alkyl peak at $36 \mathrm{ppm}$. This intensity is shared only by Eocene Australian Class Ib-correlated amber from Anglesea and Strahan (Coward et al., 2018, Type A therein). This contrasts with the ${ }^{13} \mathrm{C}$ solid-state NMR spectra of other Class Ib ambers where, if present, the $42 \mathrm{ppm}$ peak was never seen to exceed the intensity of neighbouring alkyl peaks at 19 and 27 ppm (Lambert et al., 1993; Lambert and Poinar, 2002; Lyons et al., 2009). Two further spectral features of Chatham amber, a peak at $1005 \mathrm{~cm}^{-1}$ in FTIR, and a minor resonance at $32 \mathrm{ppm}$ in ${ }^{13} \mathrm{C}$ solid-state NMR, were both found to be absent from the spectra of all other Australasian ambers (Lambert et al., 1993; Lyons et al., 2009; Seyfullah et al., 2015; Coward et al., 2018). Whilst the Australasian resins compared above, including Chatham amber, all have spectra typical of AraucariaceaeCupressaceae, the mentioned differences suggest Chatham amber does not share a common botanical source with other Australasian amber deposits. As such, it is unlikely that members of the taxodioid Cupressaceae were significant contributors to the known Cenozoic amber localities of Australasia.
4.4. Comparisons to Late Cretaceous New Jersey ambers and their botanical sources

Outcrops of the Raritan Formation of New Jersey, USA, are a copious source of Late Cretaceous amber, and contain a large diversity of plant, animal and fungal bioinclusions (Langenheim, 2003). These amber deposits are particularly relevant to those of the Chatham Islands because both units have: (1) near-coeval, Late Cretaceous ages (Raritan and Magothy formations: Cenomanian-Santonian [Brenner, 1967; Christopher, 1979], although most ambers are from the Turonian strata of the Raritan Formation [Grimaldi and Nascimbene, 2010]; Tupuangi Formation: Cenomanian-Turonian [Mildenhall, 1994, Mays and Stilwell, 2013]); (2) resiniferous Protodammara specimens (Hollick and Jeffrey, 1906; Hollick and Jeffrey, 1909; Mays et al., 2017b); and (3) an abundance of Cupressaceae fossils (New Jersey: Hollick and Jeffrey, 1909; Escapa et al., 2016; Chatham Islands: Mays, 2015; Mays et al., 2017c; Mays and Cantrill, 2018). Early studies employing PyGC-MS on Raritan Formation amber attributed an Araucariaceae affinity (Langenheim, 1969; Grimaldi et al., 1989). An araucarian source was supported by early ${ }^{13} \mathrm{C}$ solid-state NMR studies of dispersed Cretaceous ambers from the Magothy Formation, New Jersey (Lambert et al., 1990; Lambert et al., 1996). Later, Grimaldi et al. (2000) questioned the botanical source(s) of the Raritan Formation amber by applying Py-GC-MS to both dispersed amber, and in situ resins found within fossil wood; these indicated a Pinaceae or Cupressaceae source. Anderson (2006) established two distinct populations of Class Ib amber from the Raritan Formation, both of which had signatures of callitrisate; amongst extant resin-producing plants, this compound is only found in Cupressaceae. The consensus appears to be converging on members of the Cupressaceae as the primary sources of New Jersey amber, with possible contributions from Pinaceae.

Grimaldi et al. (2000) also employed direct temperature-resolved mass spectrometry (DT-MS) on the resins recovered from 'Dammara' Lamarck of the Raritan Formation. 'Dammara', an informally named group of dispersed fossil ovuliferous complexes, have been found in numerous Upper Cretaceous strata of the Northern Hemisphere (see review by Grimaldi et al., 2000). These analyses supported a Pinaceae or Cupressaceae affinity (Grimaldi et al., 2000). Furthermore, they have been found within the same stratigraphic unit as the Protodammara type species $P$. speciosaHollick and Jeffrey, 1906. Because of similarities in morphology (Mays and Cantrill, 2018), high resin canal volumes, and concurrence with abundant fossil charcoal (Grimaldi et al., 2000; Grimaldi and Nascimbene, 2010), these organs likely served a similar function to the cupressaceous Protodammara: as a seed-dispersal mechanism in post-fire environments (Mays et al., 2017b). These similarities in morphology and inferred ecological niche to Protodammara suggest a Cupressaceae affinity for 'Dammara'. It is predicted that further chemical analyses of Protodammara and 'Dammara', in particular pyrolysis-GCmatrix isolation FTIR-MS (sensu Anderson, 2006), should identify cupressaceous compounds (e.g., callitrisate), and provide strong support of this affinity.

\section{Conclusions}

Late Cretaceous amber is found as dispersed pieces throughout the Cenomanian (99-94 Ma) strata of the Chatham Islands, or in situ within the conifer fossils $P$. reimatamoriori, a member of an extinct Cupressaceae stem group. These fossil resin populations are chemically indistinguishable; as such, the primary producers of Chatham amber are likely members of Cupressaceae. By employing ${ }^{13} \mathrm{C}$ solid-state NMR, we have classified these specimens as Group A (sensu Lambert et al., 2008), which correlates to Class Ib amber (sensu Anderson et al., 1992). These categories have been generally associated with the conifer family Araucariaceae, but a link to Cupressaceae has also been definitively demonstrated in some cases. FTIR analyses support this broad categorisation; furthermore, a novel FTIR band ratio may help to 
distinguish between these two resin-producing groups of conifers. In order to maximise the reliability of comparisons with this additional band ratio, taphonomy must be accounted for, and large samples sizes are encouraged. The FTIR spectra of Chatham amber share some key features with Araucariaceae, reflecting a relatively high abundance of ester bonds. We propose two mutually compatible factors for these similarities: (1) the newly proposed band ratio is susceptible to influence by thermal maturation - the morphology and anatomy of $P$. reimatamoriori are indicative of a fire-adaptation, and thermal maturation experiments have revealed comparable chemical responses, so pre-burial heating may be responsible for the distinctive FTIR signature; and (2) due to the phylogenetic placement of Protodammara amongst the basal Cupressaceae, it likely shares more chemotaxonomic traits with Araucariaceae than resins of more derived cupressaceous taxa. Due to the age, and co-occurrence of abundant Cupressaceae fossils, including Protodammara and other closely-related resiniferous ovuliferous complexes, the amber deposits of the Chatham Islands are analogous to the better-studied ambers of the Raritan Formation, New Jersey, USA. Although generally small in size, amber is both common and stratigraphically extensive in the Tupuangi Formation of the Chatham Islands, supporting previous fossil evidence of a Cupressaceaedominated flora at southern polar latitudes throughout the globally warm early Late Cretaceous.

Supplementary data to this article can be found online at https://doi. org/10.1016/j.revpalbo.2018.08.004.

\section{Acknowledgements}

The authors would like to thank the members of the Monash Palaeontology Undergraduate Volunteer Program for assistance with fossil preparation, with special thanks to Chief Preparator Chava Rodriguez. Field assistance was provided by Pedro Viegas and Tim Ziegler. Special thanks go to palaeobotanical artist Mali Moir. We would like to thank Jeffrey Stilwell and Antonio Patti for a series of helpful discussions. Deakin University's Advanced Characterisation Facility is acknowledged for use of the NMR instrument. Donna and Terry Tuanui, and Celine and Dianne Gregory-Hunt kindly provided support on the Chatham Islands. The authors thank Chief Editor Michael Stephenson, and two anonymous reviewers; their recommendations vastly improved the quality of the manuscript. Fieldwork and research supported by National Geographic Society (grant 9761-15) awarded to C.M.; additional financial support provided by the Paleontological Society and Monash University. C.M. would like to acknowledge the Moriori people as the original landowners of Rēkohu (the Chatham Islands).

\section{References}

Abduriyim, A , Hideaki, K, Yukihiro, Y, Hiroyuki, N , Masao, W Tadashi, S, Masataka, T, Shinobu, O., 2009. Characterization of "green amber" with infrared and nuclear magnetic resonance spectroscopy. Gems \& Gemology 45, 158-177.

Anderson, K.B., 1995. New evidence concerning the structure, composition and maturation of class I (polylabdanoid) resinites. In: Anderson, K.B., Crelling, J.C. (Eds.) Amber, Resinite and Fossil Resins. Symposium Series 617. American Chemical Society, Washington, DC, pp. 105-129.

Anderson, K.B, 2006. The nature and fate of natural resins in the geosphere. XII. Investigation of C-ring aromatic diterpenoids in Raritan amber by pyrolysis-GC-matrix isolation FTIR-MS. Geochemical Transactions 7 (2), 9

Anderson, K.B., Botto, R.E., 1993. The nature and fate of natural resins in the geosphere-lll. Re-evaluation of the structure and composition of Highgate Copalite and Giessite. Organic Geochemistry 20, 1027-1038.

Anderson, K.B., Lepage, B.A., 1995. The nature and fate of natural resins in the geosphere VI. Analysis of fossil resins from Axel Heiberg Island, Canadian Arctic. In: Anderson, K.B., Crelling, J.C. (Eds.), Symposium Series 617. Amber, Resinite and Fossil Resins. American Chemical Society, Washington, DC, USA, pp. 170-192.

Anderson, K.B., Winans, R.E., 1991. The nature and fate of natural resins in the geosphere I. Evaluation of pyrolysis-gas chromatography/mass spectrometry for the analysis of natural resins and resinites. Analytical Chemistry 63, 2901-2908.

Anderson, K.B., Winans, R.E., Botto, R.E., 1992. The nature and fate of natural resins in the geosphere II. Identification, classification and nomenclature of resinites. Organic Geochemistry $18,829-841$.
Barclay, R.S., McElwain, J.C., Sageman, B.B., 2010. Carbon sequestration activated by a volcanic $\mathrm{CO}_{2}$ pulse during ocean anoxic event 2. Nature Geoscience 3, 205-208.

Beck, C.W., 1999. The chemistry of amber. In: Alonso, J., Corral, J.C., López, R. (Eds.), Proceedings of the World Congress on Amber Inclusions, 20-23 October 1998. Estudios del Museo de Ciencias Naturales de Álava 14. Vitoria-Gasteiz, Basque, Spain, pp. 33-48.

Bice, K.L., Birgel, D., Meyers, P.A., Dahl, K.A., Hinrichs, K.-U., Norris, R.D., 2006. A multiple proxy and model study of cretaceous upper ocean temperatures and atmospheric $\mathrm{CO}_{2}$ concentrations. Paleoceanography 21, 17 PA2002.

Brenner, G.J., 1967. Early angiosperm pollen differentiation in the Albian to Cenomanian deposits of Delaware (U.S.A.). Review of Palaeobotany and Palynology 1, 219-227.

Campbell, H.J., Andrews, P.B., Beu, A.G., Maxwell, P.A., Edwards, A.R., Laird, M.G., Hornibrook, N.D.B., Mildenhall, D.C., Watters, W.A., Buckeridge, J.S., Lee, D.E., Strong, C.P., Wilson, G.J., Hayward, B.W., 1993. Cretaceous-Cenozoic geology and biostratigraphy of the Chatham Islands, New Zealand. Monograph, 2. Institute of Geological and Nuclear Sciences Limited, Lower Hutt, New Zealand.

Cantrill, D.J., Poole, I., 2002. Cretaceous patterns of floristic change in the Antarctic Peninsula. In: Crame, J.A., Owen, A.W. (Eds.), Palaeobiogeography and Biodiversity Change: The Ordovician and Mesozoic-Cenozoic Radiations. Geological Society, Special Publications 194. Geological Society, London, UK, pp. 141-152.

Christopher, R.A., 1979. Normapolles and triporate pollen assemblages from the Raritan and Magothy Formations (Upper Cretaceous) of New Jersey. Palynology 3, 73-121.

Coward, A.J., Mays, C., Patti, A.F., Stilwell, J.D., Viegas, P., O'Dell, L., 2018. Taphonomy and chemotaxonomy of Eocene amber from southeastern Australia. Organic Geochemistr $118,103-115$.

Drinnan, A.N., Crane, P.R., 1990. Cretaceous paleobotany and its bearing on the biogeography of austral angiosperms. In: Taylor, T.N., Taylor, E.L. (Eds.), Antarctic Palaeobiology and its Role in the Reconstruction of Gondwana. Springer-Verlag, New York, USA, pp. 192-219.

Escapa, I.H., Gandolfo, M.A., Crepet, W.L., Nixon, K.C., 2016. A new species of Athrotaxites (Athrotaxoideae, Cupressaceae) from the Upper Cretaceous Raritan Formation, New Jersey, USA. Botany 94, 831-845.

Farjon, A., 2005. A Monograph of Cupressaceae and Sciadopitys. Royal Botanic Gardens, Kew, Richmond, UK.

Friedrich, O., Norris, R.D., Erbacher, J., 2012. Evolution of middle to Late Cretaceous oceans -A 55 m.y. record of Earth's temperature and carbon cycle. Geology 40, 107-110.

Grimaldi, D.A., Nascimbene, P.C., 2010. Raritan (New Jersey) amber. In: Penney, D. (Ed.), Biodiversity of Fossils in Amber from the Major World Deposits. Siri Scientific Press, Manchester, UK, pp. 167-191.

Grimaldi, D., Beck, C.W., Boon, J.J., 1989. Occurrence, chemical characteristics, and paleontology of the fossil resins from New Jersey. American Museum Novitates 2948, 1-28.

Grimaldi, D.A., Shedrinsky, A., Wampler, T.P., 2000. A remarkable deposit of fossiliferous amber from the Upper Cretaceous (Turonian) of New Jersey. In: Grimaldi, D.A. (Ed.), Studies of Amber, with Particular Reference to the Cretaceous of New Jersey. Backhuys Publishers, Leiden, pp. 1-76.

Grimalt, J.O., Simoneit, B.R.T., Hatcher, P.G., Nissenbaum, A., 1988. The molecular composition of ambers. Organic Geochemistry 13, 677-690

Guiliano, M., Asia, L., Onoratini, G., Mille, G., 2007. Applications of diamond crystal ATR FTIR spectroscopy to the characterization of ambers. Spectrochimica Acta, Part A: Molecular and Biomolecular Spectroscopy 67, 1407-1411.

Hammer, Ø., Harper, D.A.T., Ryan, P.D., 2001. PAST: Paleontological statistics software package for education and data analysis. Palaeontologia Electronica 4 (4), 9.

Herman, A.B., Spicer, R.A., 2010. Mid-Cretaceous floras and climate of the Russian high Arctic (Novosibirsk Islands, Northern Yakutiya). Palaeogeography, Palaeoclimatology, Palaeoecology 295, 409-422.

Hollick, A., Jeffrey, E.C., 1906. Affinities of certain Cretaceous plant remains commonly referred to the genera Dammara and Brachyphyllum. American Naturalist 40, 189-215.

Hollick, A., Jeffrey, E.C., 1909. Studies of cretaceous coniferous remains from Kreischerville, New York. Memoirs of the New York Botanical Garden 3, 1-138.

Jeffrey, A.C., Chrysler, M.A., 1906. On Cretaceous Pityoxyla. Botanical Gazette 42, 1-15.

Lambert, J.B., Frye, J.S., 1982. Carbon functionalities in amber. Science 217, 55-57.

Lambert, J.B., Poinar, G.O., 2002. Amber: The organic gemstone. Accounts of Chemical Research 35, 628-636.

Lambert, J.B., Frye, J.S., Poinar, G.O., 1985. Amber from the Dominican Republic: analysis by nuclear magnetic resonance spectroscopy. Archaeometry 27, 43-51.

Lambert, J.B., Beck, C.W., Frye, J.S., 1988. Analysis of European amber by carbon-13 nuclear magnetic resonance spectroscopy. Archaeometry 30, 248-263.

Lambert, J.B., Frye, J.S., Poinar, G.O., 1990. Analysis of North American amber by carbon-13 NMR spectroscopy. Geoarchaeology 5, 43-52.

Lambert, J.B., Johnson, S.C., Poinar, G.O., Frye, J.S., 1993. Recent and fossil resins from New Zealand and Australia. Geoarchaeology 8, 141-155.

Lambert, J.B., Johnson, S.C., Poinar Jr., G.O., 1996. Nuclear magnetic resonance characterization of Cretaceous amber. Archaeometry 38, 325-335.

Lambert, J.B., Kozminski, M.A., Santiago-Blay, J.A., 2007. Distinctions among conifer exudates by proton magnetic resonance spectroscopy. Journal of Natural Products 70 , 1283-1294.

Lambert, J.B., Santiago-Blay, J.A., Anderson, K.B., 2008. Chemical signatures of fossilized resins and recent plant exudates. Angewandte Chemie International Edition 47, 9608-9616.

Lambert, J.B., Heckenbach, E.A., Wu, Y., Santiago-Blay, J.A., 2010. Characterization of plant exudates by principal-component and cluster analyses with nuclear magnetic resonance variables. Journal of Natural Products 73, 1643-1648.

Lambert, J.B., Tsai, C.Y.-H., Shah, M.C., Hurtley, A.E., Santiago-Blay, J.A., 2012. Distinguishing amber and copal classes by proton magnetic resonance spectroscopy. Archaeometry 54, 332-348.

Lambert, J.B., Santiago-Blay, J.A., Wu, Y., Levy, A.J., 2015. Examination of amber and related materials by NMR spectroscopy. Magnetic Resonance in Chemistry 53, 2-8. 
Lamont, B.B., Le Maitre, D.C., Cowling, R.M., Enright, N.J., 1991. Canopy seed storage in woody plants. Botanical Review 57, 277-317.

Langenheim, J.H., 1969. Amber: A botanical inquiry. Science 163, 1157-1169.

Langenheim, J.H., 2003. Plant Resins: Chemistry, Evolution, Ecology, and Ethnobotany. Timber Press, Inc, Portland, Oregon, USA.

Langenheim, J.H., Beck, C.W., 1965. Infrared spectra as a means of determining botanical sources of amber. Science 149, 52-55.

Lyons, P.C., Mastalerz, M., Orem, W.H., 2009. Organic geochemistry of resins from modern Agathis australis and Eocene resins from New Zealand: Diagenetic and taxonomic implications. International Journal of Coal Geology 80, 51-62.

Mao, K., Milne, R.I., Zhang, L., Peng, Y., Liu, J., Thomas, P., Mill, R.R., Renner, S.S., 2012. Distribution of living Cupressaceae reflects the breakup of Pangea. Proceedings of the National Academy of Sciences of the United States of America 109, 7793-7798.

Markwick, P.J., Rowley, D.B., Ziegler, A.M., Hulver, M., Valdes, P.J., Sellwood, B.W., 2000. Late Cretaceous and Cenozoic global palaeogeographies: mapping the transition from a "hot-house" world to an "ice-house" world. GFF 12, 103.

Martínez-Richa, A., Vera-Graziano, R., Rivera, A., Joseph-Nathan, P., 2000. A solid-state ${ }^{13} \mathrm{C}$ NMR analysis of ambers. Polymer 41, 743-750.

Mays, C., 2015. A Late Cretaceous (Cenomanian-Turonian) South Polar Palynoflora from the Chatham Islands, New Zealand. AAP Memoirs, 47. Association of Australasian Palaeontologists, Canberra, Australia.

Mays, C., Cantrill, D.J., 2018. Protodammara reimatamoriori, a new species of conifer (Cupressaceae) from the Upper Cretaceous Tupuangi Formation, Chatham Islands, Zealandia. Alcheringa (accepted 12th December, 2017).

Mays, C., Stilwell, J.D., 2013. Pollen and spore biostratigraphy of the mid-Cretaceous Tupuangi Formation, Chatham Islands, New Zealand. Review of Palaeobotany and Palynology 192, 79-102.

Mays, C., Steinthorsdottir, M., Stilwell, J.D., 2015a. Climatic implications of Ginkgoites waarrensis Douglas emend. From the south polar Tupuangi flora, Late Cretaceous (Cenomanian), Chatham Islands. Palaeogeography, Palaeoclimatology, Palaeoecology 438, 308-326.

Mays, C., Tosolini, A.-M.P., Cantrill, D.J., Stilwell, J.D., 2015b. Late Cretaceous (Cenomanian-Turonian) macroflora from the Chatham Islands, New Zealand: bryophytes, lycophytes and pteridophytes. Gondwana Research 27, 1042-1060.

Mays, C., Bevitt, J.J., Stilwell, J.D., 2017a. Pushing the limits of neutron tomography in palaeontology: three-dimensional modelling of in situ resin within fossil plants. Palaeontologia Electronica 20 (3.57A), 1-12.

Mays, C., Cantrill, D.J., Bevitt, J.J., 2017b. Polar wildfires and conifer serotiny during the cretaceous global hothouse. Geology 45, 1119-1122.

Mays, C., Cantrill, D.J., Stilwell, J.D., Bevitt, J.J., 2017c. Neutron tomography of Austrosequoia novae-zeelandiae comb. nov. (Late Cretaceous, Chatham Islands, New Zealand): Implications for Sequoioideae phylogeny and biogeography. Journal of Systematic Palaeontology 16, 551-570.

Mildenhall, D.C., 1994. Palynological Reconnaissance of Early Cretaceous to Holocene Sediments, Chatham Islands, New Zealand. Monograph. Institute of Geological and Nuclear Sciences Limited, Lower Hutt, New Zealand.

Otto, A., Simoneit, B.R.T., Wilde, V., Kunzmann, L., Püttmann, W., 2002a. Terpenoid composition of three fossil resins from Cretaceous and Tertiary conifers. Review of Palaeobotany and Palynology 120, 203-215.

Otto, A., White, J.D., Simoneit, B.R.T., 2002b. Natural product terpenoids in Eocene and Miocene conifer fossils. Science 297, 1543-1545.

Otto, A., Simoneit, B.R.T., Rember, W.C., 2003. Resin compounds from the seed cones of three fossil conifer species from the Miocene Clarkia flora, Emerald Creek, Idaho, USA, and from related extant species. Review of Palaeobotany and Palynology 126, 225-241.

Otto, A., Simoneit, B.R.T., Wilde, V., 2007. Terpenoids as chemosystematic markers in selected fossil and extant species of pine (Pinus, Pinaceae). Botanical Journal of the Linnean Society 154, 129-140.
Pastorelli, G., Richter, J., Shashoua, Y., 2011. Photoageing of Baltic amber - Influence of daylight radiation behind window glass on surface colour and chemistry. Polymer Degradation and Stability 96, 1996-2001.

Pastorelli, G., Shashoua, Y., Richter, J., 2013. Hydrolysis of Baltic amber during thermal ageing: an infrared spectroscopic approach. Spectrochimica Acta, Part A: Molecular and Biomolecular Spectroscopy 106, 124-128.

Perrichot, V., Boudinot, B.E., Cole, J., Delhaye-Prat, V., Esnault, J., Goldman, Y., Nohra, Y.A. Schmidt, A.R., 2016. African fossiliferous amber: a review. In: Penney, D., Ross, A.J. (Eds.), 7th International Conference on Fossil Insects, Arthropods and Amber Edinburgh, UK, p. 41.

Pole, M.S., Philippe, M., 2010. Cretaceous plant fossils of Pitt Island, the Chatham group, New Zealand. Alcheringa 34, 231-263.

Poulin, J., Helwig, K., 2012. Class Id resinite from Canada: A new sub-class containing succinic acid. Organic Geochemistry 44, 37-44.

Poulin, J., Helwig, K., 2014. Inside amber: the structural role of succinic acid in Class Ia and Class Id resinite. Analytical Chemistry 86, 7428-7435.

Poulin, J., Helwig, K., 2015. Inside amber: New insights into the macromolecular structure of Class Ib resinite. Organic Geochemistry 86, 94-106.

Raine, J.I., Beu, A.G., Boyes, A.F., Campbell, H.J., Cooper, R.A., Crampton, J.S., Crundwell, M.P., Hollis, C.J., Morgans, H.E.G., 2015. Revised calibration of the New Zealand Geological Timescale: NZGT2015/1. GNS Science Report 2012 (39), 1-53.

Rothwell, G.W., Stockey, R.A., Mapes, G., Hilton, J., 2011. Structure and relationships of the Jurassic conifer seed cone Hughmillerites juddii gen. et comb. nov.: Implications for the origin and evolution of Cupressaceae. Review of Palaeobotany and Palynology 164 45-59.

Schellart, W.P., Lister, G.S., Toy, V.G., 2006. A Late Cretaceous and Cenozoic reconstruction of the Southwest Pacific region: Tectonics controlled by subduction and slab rollback processes. Earth-Science Reviews 76, 191-233.

Seyfullah, LJ., Sadowski, E.M., Schmidt, A.R, 2015. Species-level determination of closely related araucarian resins using ftir spectroscopy and its implications for the provenance of New Zealand amber. PeerJ 2015.

Shashoua, Y., Berthelsen, M.B.L.D., Nielsen, O.F., 2005. Raman and ATR-FTIR spectroscopies applied to the conservation of archaeological Baltic amber. Journal of Raman Spectroscopy 37, 1221-1227.

Sutherland, R., 1999. Basement geology and tectonic development of the greater New Zealand region: an interpretation from regional magnetic data. Tectonophysics 308 , 341-362.

Tappert, R., Wolfe, A.P., McKellar, R.C., Tappert, M.C., Muehlenbachs, K., 2011. Characterizing modern and fossil gymnosperm exudates using micro-Fourier transform infrared spectroscopy. International Journal of Plant Science 172, 120-138.

van Aarssen, B.G.K., de Leeuw, J.W., Collinson, M., Boon, J.J., Goth, K., 1994. Occurrence of polycadinene in fossil and recent resins. Geochimica et Cosmochimica Acta 58 223-229.

Wang, Y., Yang, M., Nie, S., Liu, F., 2017. Gemmological and spectroscopic features of untreated vs. heated amber. Journal of Gemmology 35, 530-542.

Wolfe, A.P., McKellar, R.C., Tappert, R., Sodhi, R.N.S., Muehlenbachs, K., 2016. Bitterfeld amber is not Baltic amber: three geochemical tests and further constraints on the botanical affinities of succinite. Review of Palaeobotany and Palynology 225, 21-32.

Wolfe, A.P., Tappert, R., Muehlenbachs, K., Boudreau, M., McKellar, M.C., Basinger, J.C. Garrett, A., 2009. A new proposal concerning the botanical origin of Baltic amber. Proceedings of the Royal Society B 276, 3403-3412.

Wood, R.A., Andrews, P.B., Herzer, R.H., Hornibrook, N.D.B., Hoskins, R.H., Beu, A.G. Maxwell, P.A., Keyes, I.W., Raine, J.I., Mildenhall, D.C., Wilson, G.J., Smale, D., Soong, R., Watters, W.A., 1989. Cretaceous and Cenozoic Geology of the Chatham Rise, South Island, New Zealand. New Zealand Geological Survey Basin Studies. New Zealand Geological Survey, Lower Hutt, New Zealand. 